\title{
Homoplantaginin Modulates Insulin Sensitivity in Endothelial Cells by Inhibiting Inflammation
}

\author{
Feihua Wu, ${ }^{* a}$ Hui Wang, ${ }^{a}$ Juan $\mathrm{Li}^{a},{ }^{a}$ Jingyu Liang, ${ }^{b}$ and Shiping $\mathrm{Ma}^{a}$ \\ ${ }^{a}$ Department of Pharmacology for Chinese Materia Medica, China Pharmaceutical University; and ${ }^{b}$ Department of \\ Natural Medicinal Chemistry, China Pharmaceutical University; 639 Longmian Avenue, Jiangning District, Nanjing \\ 211198, China. Received October 7, 2011; accepted April 5, 2012
}

Recent data have indicated that inflammation plays an important role in the development of insulin resistance. The present study aims at examining the activity of homoplantaginin, a flavonoid from a traditional Chinese medicine Salvia plebeia R. BR., on palmitic acid (PA)-induced insulin sensitivity and the underlying mechanisms of its anti-infammatory properties in the endothelial cells. Pre-treatment of homoplantaginin on human umbilical vein endothelial cells (HUVECs) significantly inhibited PA induced tumour necrosis factor- $\alpha$ (TNF- $\alpha$ ) and interleukin-6 (IL-6) mRNA expression, and inhibitory $\kappa$ B kinase beta (IKK $\beta$ ) and nuclear factor- $\kappa \mathrm{B}(\mathrm{NF}-\boldsymbol{\kappa} \mathrm{B})$ p 65 phosphorylation. To the PA-impaired insulin-dependent tyrosine phosphorylation of insulin receptor substrate-1 (IRS-1) and decrease in nitric oxide (NO) production, pretreatment of homoplantaginin could effectively reverse the effects of PA. Additionally, homoplantaginin significantly modulated the Ser/Thr phosphorylation of IRS-1, improved phosphorylation of Akt and endothelial nitric oxide synthase (eNOS), and increased NO production in the presence of insulin. Taken together, our results demonstrated that homoplantaginin ameliorates endothelial insulin resistance by inhibiting inflammation and modulating cell signalling via the IKK/IRS-1/pAkt/peNOS pathway, suggesting it may be used for the prevention and treatment of endothelial dysfunction associated with insulin resistance.

Key words homoplantaginin; inflammation; insulin resistance; endothelial cell

Insulin resistance is one of the defining clinical features of metabolic syndrome (MetS) and is especially characteristic of most patients with type 2 diabetes mellitus (T2DM). Endothelial dysfunction is widespread among type 2 diabetes patients and individuals with insulin-resistant conditions. ${ }^{1)}$ Endothelial dysfunction is a hallmark of diabetic vascular disease and can be described as an impairment of the generation and function of nitric oxide (NO), a vasodilator and vascular homeostatic agent. ${ }^{2)}$ One of the physiological actions of insulin in the vasculature is to promote vasodilation by increasing NO production. In endothelial cells, insulin increases NO production through an insulin receptor substrate-1 (IRS-1) and phosphatidylinositol 3-kinase(PI3-kinase)-dependent pathway ${ }^{3}$ that mediates the phosphorylation of endothelial nitric oxide synthase (eNOS) by Akt in a calcium-independent manner. ${ }^{4}$

In recent years, low grade inflammation has been identified as one of the factors associated with endothelial dysfunction in subjects with type 2 diabetes, ${ }^{1)}$ with free fatty acids (FFAs) representing one class of inflammatory factors involved in the process. ${ }^{5)}$ It has been reported that the plasma free fatty acid elevation is closely related to the development of insulin resistance. ${ }^{6)}$ FFAs have also been shown to activate inhibitory $\kappa \mathrm{B}$ kinase beta $(\operatorname{IKK} \beta)$, a serine kinase that controls the activation of the inflammation- associated nuclear factor- $\kappa \mathrm{B}$ (NF$\kappa \mathrm{B})$ transcription factor. FFAs increase IRS-1 serine phosphorylation in cultured endothelial cells, which subsequently reduces insulin-dependent IRS-1 tyrosine phosphorylation, decreasing the activation of PI3-kinase and NO production. ${ }^{7}$ )

Homoplantaginin is believed to be the main flavonoid component in Salvia plebeia R. BR. (Labiatae), ${ }^{8)}$ a traditional chinese medicine used for the treatment of a variety of inflammatory diseases including hepatitis, cough, diarrhea, gonorrhea, menorrhagia, tumors and hemorrhoids. $\left.{ }^{9}\right)$ Salvia plebeia R. BR. was identified to be a potent antioxidant plant. ${ }^{10)}$ The compound homoplantaginin in Salvia plebeia could ameliorate liver injury. Homoplantaginin markedly decreased the levels of tumour necrosis factor- $\alpha$ (TNF- $\alpha$ ) and interleukin-1 (IL-1) in Bacillus Calmette-Guérin/lipopolysaccharide-induced hepatic injury mice. ${ }^{11)}$ Our previous study revealed that homoplantaginin could significantly attenuate hyperlipidemia and hyperglycemia in diabetic mice. ${ }^{12)}$ However, its anti-inflammatory potency in the endothelium, particularly in the context of endothelial insulin resistance, has not been reported. In this study, we investigated the effect of homoplantaginin on FFAinduced insulin resistance in endothelial cells and to better understand the relative mechanism underlying its regulation of insulin signaling transduction.

\section{MATERIALS AND METHODS}

Reagents Palmitate acid (PA, Sinopharm Chemical Reagent Co., Ltd., China) was dissolved in ethanol at $200 \mathrm{~mm}$ as stock solution and further diluted to $5 \mathrm{~mm}$ with $10 \%$ FFAfree and low endotoxin bovine serum albumin before the use. Sodium salicylate was purchased from Tianjin Kemiou Chemical Agent Center; (3-[4,5-dimetylthiazol-2-yl]-2,5-diphenyltetrazolium bromide (MTT) and insulin were purchased from Sigma-Aldrich (St. Louis, MO, U.S.A.). Phospho-IRS-1 (Ser307), IRS-1(R301) and glyceraldehyde-3-phosphate dehydrogenase (GAPDH) monoclonal antibodies were purchased from Bioworld Technology, MN, U.S.A. Phospho-Akt (T308), Akt (A444), phospho-eNOS (Ser1177), phospho-NF- $\kappa$ B p65 (Ser536), NF- $\kappa$ B p65, phospho-IKK $\beta$ (Y199), and IKK $\beta$ (F182) monoclonal antibodies were purchased from Cell Signaling Technology (Beverly, MA, U.S.A.).

Isolation and Purification of Homoplantaginin Powdered herbs of Salvia plebeia R. BR. were refluxed with $85 \%$ ethanol three times. The extract was suspended in water and successively partitioned with petroleum ether, ethyl acetate (EtOAc). The EtOAc fraction was separated by silica gel 
column chromatography using a gradient of $\mathrm{CHCl}_{3} / \mathrm{CH}_{3} \mathrm{OH}$ $(100: 1 \rightarrow 1: 1)$, then $\mathrm{CHCl}_{3} / \mathrm{CH}_{3} \mathrm{OH}(100: 8)$ fraction was subjected to Sephadex LH-20 column chromatography to obtain homoplantaginin. The chemical structure was identified through spectroscopic analysis as reported previously. ${ }^{13)}$ The purity of this compound was determined to be higher than $98 \%$ by normalization of the peak area detected by high-performance liquid chromatography (HPLC). Homoplantaginin was dissolved in dimethyl sulfoxide (DMSO) as a stock solution, stored at $-20^{\circ} \mathrm{C}$, and diluted with medium before each experiment. The final DMSO concentration did not exceed $0.1 \%$ DMSO throughout the study (control groups were always treated with $0.1 \%$ DMSO in the corresponding experiments).

Cell Culture The human umbilical vein endothelial cells (HUVECs) were obtained from the Shanghai Institute of Cell Biology, Chinese Academy of Sciences. The cells were cultured at $37^{\circ} \mathrm{C}$ under a humidified atmosphere containing $5 \%$ $\mathrm{CO}_{2}$ and $95 \%$ air atmosphere in Dulbecco's modified Eagle's medium (DMEM), supplemented with $10 \%$ fetal calf serum, $100 \mathrm{U} / \mathrm{mL}$ penicillin and $100 \mathrm{U} / \mathrm{mL}$ streptomycin. When cells grew to $80 \%$ confluence, the culture medium was replaced, and the cells were starved for $24 \mathrm{~h}$ in serum-free medium prior to PA treatment.

Cell Viability Assay The viability of cultured cells was determined using the reduction of MTT to formazan. HUVECs $\left(1 \times 10^{4}\right.$ cells/well) were plated in 96-well plates and incubated at $37^{\circ} \mathrm{C}$ in a $5 \% \mathrm{CO}_{2}$ incubator. The cells were then exposed to various concentrations of homoplantaginin $(0.1,1$, $3,10,30,100 \mu \mathrm{M})$ for $48 \mathrm{~h}$. Subsequently, $20 \mu \mathrm{L}$ of MTT $(5 \mathrm{mg} /$ $\mathrm{mL}$ ) was added to each well for an additional $4 \mathrm{~h}$ at $37^{\circ} \mathrm{C}$. The supernatant was removed, and DMSO was added to dissolve the formazan crystals. The optical absorbance was measured at $540 \mathrm{~nm}$.

RNA Extraction and Reverse Transcription-Polymerase Chain Reaction (RT-PCR) IL- 6 and TNF- $\alpha$ mRNA levels in HUVECs were measured by RT-PCR method. Briefly, $1 \times 10^{6}$ cells were cultured in DMEM $(10 \%$ fetal calf serum $)$ for $24 \mathrm{~h}$. The cells were then preincubated with homoplantaginin $(0.1,1$ or $10 \mu \mathrm{M})$ or sodium salicylate $(500 \mu \mathrm{M})$ for $30 \mathrm{~min}$, followed by stimulation with PA $(100 \mu \mathrm{M})$. After $3 \mathrm{~h}$ incubation with PA, total RNA in the cells was extracted using TriZol Reagent (Invitrogen, U.S.A.). $5 \mu \mathrm{g}$ of total RNA was reversetranscribed into cDNA using an EasyScript First-Strand cDNA Synthesis SuperMix Kit (TransGen Biotech). The individual target cDNA was amplified using specific primers as follows: 5'-TAGCGGCCTCACACAGACAG-3' (sense) and 5'-GGC TGGCATATGTGCTTGGG-3' (antisense) for IL-6 (408 bp); 5'-CTCTGGCCGAGGCAGTCAGA-3' (sense) and 5'-GGC GTTTGGGAAGGTTGGAT-3' (antisense) for TNF- $\alpha$ (519bp); and 5'-ACATCTGCTGGAAGGTGGAC-3' (sense) and 5'-GGT ACCACCATGTACCCAGG-3' (antisense) for $\beta$-actin (161 bp). PCR products were subjected to electrophoresis in $1.5 \%$ agarose gels with $0.5 \mu \mathrm{g} / \mathrm{mL}$ ethidium bromide and visualised under UV light; the signal intensity was then measured using a Bio-Rad image system and analysed using Quantity One software (Bio-Rad). The mRNA levels of individual genes were normalised and represented as ratios against $\beta$-actin mRNA levels.

Western Blot Analysis After being treated with PA or insulin, HUVECs were washed twice with ice-cold phosphate-buffered saline (PBS) and lysed with lysis buffer $(1 \%$
TritonX-100, $150 \mathrm{~mm} \mathrm{NaCl}, 50 \mathrm{~mm}$ Tris- $\mathrm{HCl} \mathrm{pH} 8.0,10 \mu \mathrm{g} /$ $\mathrm{mL}$ leupeptin, $20 \mu \mathrm{g} / \mathrm{mL}$ aprotinin, $125 \mu \mathrm{M}$ dithiothreitol, $1 \mathrm{~mm}$ phenylmethylsulfonyl fluoride (PMSF), and $1 \mathrm{~mm}$ sodium orthovanadate). The cell lysates were achieved by centrifugation at $12,000 \mathrm{rpm}$ for $10 \mathrm{~min}$ at $4^{\circ} \mathrm{C}$. Equivalent amounts of protein determined by a Bradford assay were separated in a $10 \%$ sodium dodecyl sulfate-polyacrylamide gel electrophoresis (SDS-PAGE), and subsequently transferred to polyvinylidene difluoride (PVDF) membranes (Millipore). After blocking in a solution $(5 \%$ skimmed milk in Tris-buffered saline (TBS) containing $0.05 \%$ Tween 20 ), the membranes were incubated with primary antibody (1:1000 dilution) at $4^{\circ} \mathrm{C}$ overnight. Then membranes were washed and reacted with horseradish peroxidase (HRP)-labeled anti-rabbit immunoglobulin G (1:2000 dilution) for $1 \mathrm{~h}$ at $37^{\circ} \mathrm{C}$. Membranes were incubated with an enhanced chemical luminescence detection solution and exposed to X-ray film. The resulting images were analyzed with Image $\mathbf{J}$ software (National Institutes of Health, U.S.A.).

Measurement of Intracellular NO Production The NO-specific fluorescent dye 4-amino, 5-aminomethyl-2',7'difluorescein, diacetate (DAF-FM DA) was used to assess NO production in endothelial cells as described previously. ${ }^{14}$ Briefly, HUVECs $\left(1 \times 10^{4}\right.$ cells/well $)$ were incubated with homoplantaginin $(0.1$ or $1 \mu \mathrm{M})$ or sodium salicylate $(500 \mu \mathrm{M})$ for $30 \mathrm{~min}$, followed by stimulation with PA $(100 \mu \mathrm{M})$ for $3 \mathrm{~h}$. After being washed with cold PBS, the cells were treated with $5 \mu \mathrm{M}$ DAF-FM DA for $30 \mathrm{~min}$ at $37^{\circ} \mathrm{C}$. Subsequently, residual extracellular chromophore was washed away with ice-cold PBS and insulin (100 nM) or diluent was added for $5 \mathrm{~min}$. The cells were then fixed with $4 \%$ paraformaldehyde for $5 \mathrm{~min}$ at $4^{\circ} \mathrm{C}$. The fluorescence in fixed cells was measured using an Olympus fluorescence microscope (Olympus, IX51S8F-3) with excitation and emission wavelengths of 495 and of $515 \mathrm{~nm}$, respectively. All images were taken in the first $30 \mathrm{~s}$ of light exposure to avoid fluorescence decay. Fluorescence intensity of the images was analyzed with Image J software (National Institutes of Health, U.S.A.).

Statistic Analysis All data are expressed as mean \pm S.D. from three or four independent experiments. Statistical differences were evaluated by the one-way analysis of variance (ANOVA) and two-tailed Student's $t$-test. A $p<0.05$ was considered significant.

\section{RESULTS}

Effect of Homoplantaginin on the Viability of HUVECs HUVECs were cultured with various concentrations of homoplantaginin for $48 \mathrm{~h}$, and cell viability was evaluated using the MTT assay. As shown in Fig. 1, treatment with homoplantagi$\operatorname{nin}(0.1,1,3,10,30$ and $100 \mu \mathrm{M})$, the cell viability was $103 \%$, $95 \%, 99 \%, 100 \%, 101 \% 99 \%$ of the blank, respectively. These results demonstrated that homoplantaginin did not exhibit substantial cytotoxicity on HUVECs at concentrations up to $100 \mu \mathrm{M}$.

Effects of Homoplantaginin on mRNA Expressions of Proinflammatory Cytokines and Activation of IKK/ $/ \mathbf{N F}$ $\boldsymbol{\kappa} \mathbf{B}$ in PA-Treated HUVECs To determine its anti-inflammatory activity, we first examined the effects of homoplantaginin on IL- 6 and TNF- $\alpha$ mRNA expression in PA-treated HUVECs. As shown in Fig. 2, the IL-6 and TNF- $\alpha$ mRNA levels in PA $(100 \mu \mathrm{M})$ treated HUVECs were significantly 


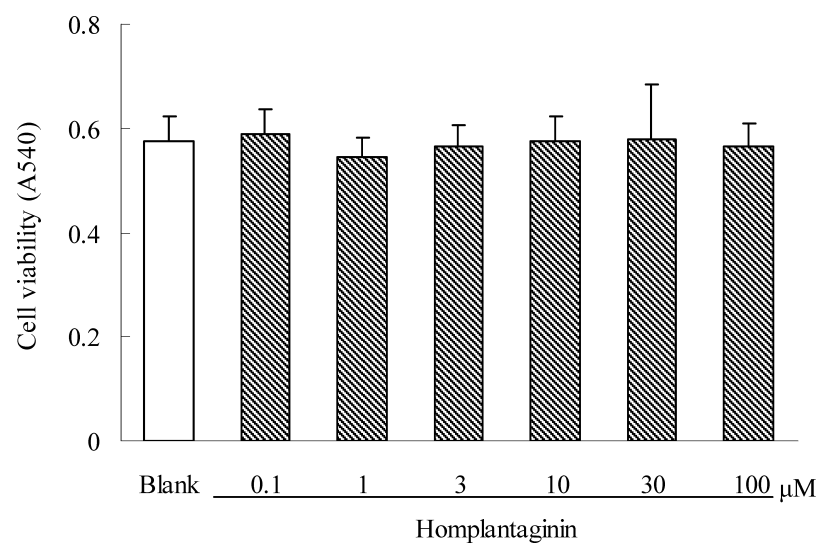

Fig. 1. Effect of Homoplantaginin on the Viability of HUVECs

Cells were cultured with various concentrations of homoplantaginin for $48 \mathrm{~h}$ in 96-well plates. Cell viability was assessed using the MTT assay. The data shown are expressed as the mean values \pm S.D. of three independent experiments.

increased by 2.7-fold and 1.7-fold, respectively, when compared to blank. Pretreatment of homoplantaginin suppressed IL- 6 mRNA expression by $20 \%, 35 \%$ and $56 \%$ and TNF- $\alpha$ mRNA expression by $46 \%, 54 \%$ and $80 \%$ at $0.1,1$ and $10 \mu \mathrm{M}$, respectively. The positive control sodium salicylate showed a similar inhibitory effect on TNF- $\alpha$ and IL- 6 mRNA expression.

$\operatorname{IKK} \beta$ is a serine kinase that controls the activation of NF$\kappa \mathrm{B}$, a transcription factor associated with inflammation, and can be activated by PA, one of the richest FFAs. As shown in Fig. 3, PA significantly increased the phosphorylation of IKK $\beta$ and NF- $\kappa \mathrm{B}$, by 1.8-fold and 4.7-fold, respectively, compared to the blank. Interestingly, pre-treatment with homoplantaginin significantly decreased PA-induced IKK $\beta$ and $\mathrm{NF}-\kappa \mathrm{B}$ phosphorylation in a dose dependent manner. Pretreatment of homoplantaginin suppressed IKK $\beta$ phosphorylation by $95 \%$, $106 \%$ and $162 \%$ and NF- $\kappa$ B phosphorylation by $57 \%, 86 \%$ and $102 \%$ at $0.1,1$ and $10 \mu \mathrm{M}$, respectively. Likewise, sodium salicylate also inhibited IKK $\beta$ and NF- $\kappa$ B activation evoked by PA. These reults suggust that homoplantaginin has significant anti-inflammatory activity on HUVECs.

Effect of Homoplantaginin on Serine Phosphorylation of IRS-1 in PA-Stimulated HUVECs To determine whether its anti-inflammatory potency could contribute to an inflammation-mediated enhancement of insulin resistance, we examined the effect of homoplantaginin on serine phosphorylation of IRS-1 in PA-stimulated HUVECs. As shown in Fig. 4, when endothelial cells were exposed to PA, the phosphorylation level of serine residue S307 in IRS-1 was increased by 2.1 fold compared to blank. When the cells were pretreated with homoplantaginin, the phosphorylation of IRS-1 S307 residue was reduced, and the inhibition was about $12 \%, 46 \%$ and $55 \%$ at $0.1,1$ and $10 \mu \mathrm{m}$, respectively. Similarly, sodium salicylate decreased the phosphorylation of IRS-1 and the inhibition ratio is $29 \%$.

Effects of Homoplantaginin on the Tyrosine Phosphorylation of IRS-1 and Phosphorylation of Akt, eNOS in HUVECs Induced by PA To further demonstrate that the anti-inflammatory potency of homoplantaginin contributed to amelioration of insulin resistance, we examined its effect on the phosphorylation of tyrosine in IRS-1 (detected by Western blot analysis using the PY99 antibody) in PA-induced

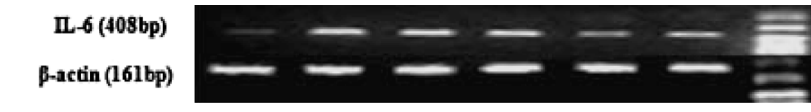

$\mathbf{A}$
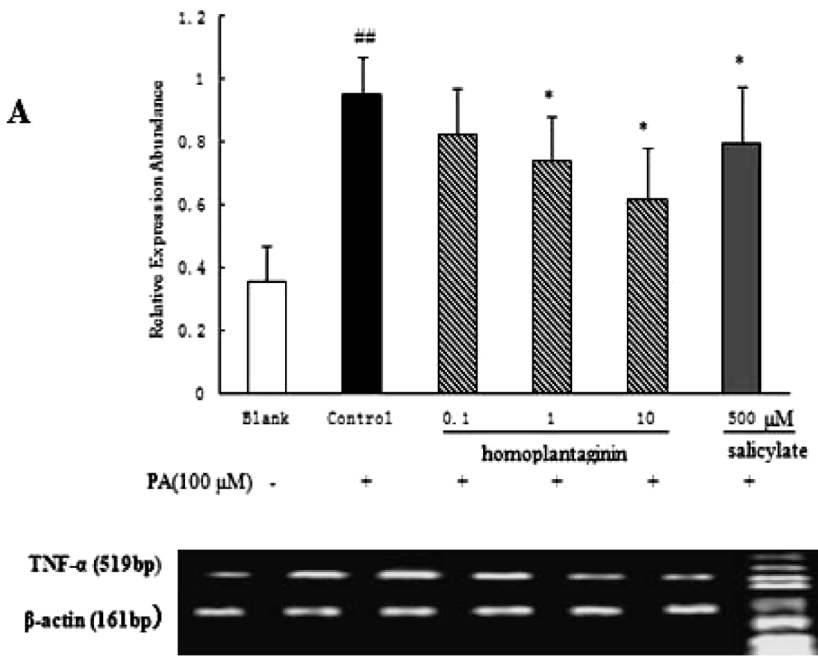

B

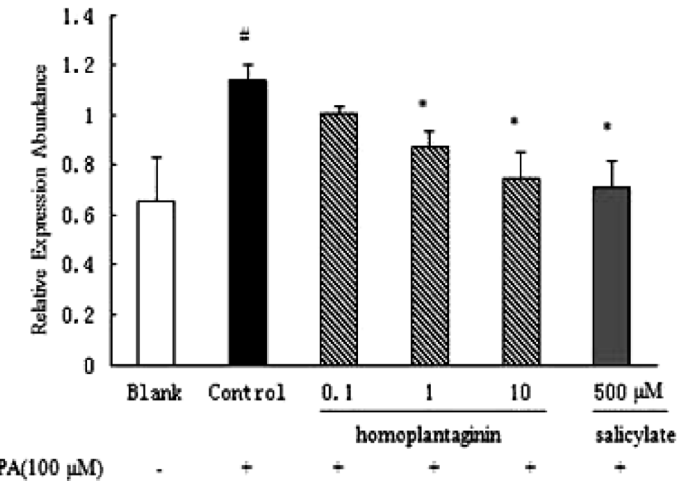

Fig. 2. Effect of Homoplantaginin on IL-6 and TNF- $\alpha$ mRNA Expression in PA-Treated HUVECs

HUVECs were pretreated with homoplantaginin or sodium salicylate for $30 \mathrm{~min}$ before being incubated with PA for $3 \mathrm{~h}$. mRNA expression levels were determined using RT-PCR. Salicylate-treated cells were used as positive controls. The data shown are expressed as the mean values \pm S.D. of three independent experiments. ${ }^{\#} p<0.05,{ }^{\#} p<0.01$ versus blank; $* p<0.05$ versus control.

endothelial cells. As shown in Fig. 5A, following PA treatment, the insulin-mediated tyrosine phosphorylation of IRS-1 was significantly reduced. Pretreatment with homoplantaginin $(0.1,1,10 \mu \mathrm{M})$ remarkably increased the level of the IRS-1 tyrosine phosphorylation, by 2.2, 2.3 and 2.6-fold, respectively, compared to control. Additionally, PA treatment significantly impaired this insulin-mediated tyrosine phosphorylation in Akt and eNOS. Pretreatment with homoplantaginin $(0.1,1$, $10 \mu \mathrm{M})$ remarkably increased Akt phosphorylation by $1.3,2.4$ and 2.8-fold (Fig. 5B), and eNOS phosphorylation by 1.1, 1.6 and 1.9-fold (Fig. 5C), respectively.

Effect of Homoplantaginin on NO Production in PATreated HUVECs Under normal circumstances, insulinstimulated Akt phosphorylation can activate eNOS to produce NO. Intracellular NO production was detected as an increase in fluorescence intensity in loaded HUVECs cells. Representative fluorescent images of DAF-FM DA-loaded cells are shown in Fig. 6A. As a result, $100 \mathrm{~nm}$ of insulin induced a significant increase in NO production, while $100 \mu \mathrm{m}$ of PA strongly abolished insulin-induced increases in NO production (Fig. 6B). In contrast, pretreatment with homoplantaginin or 

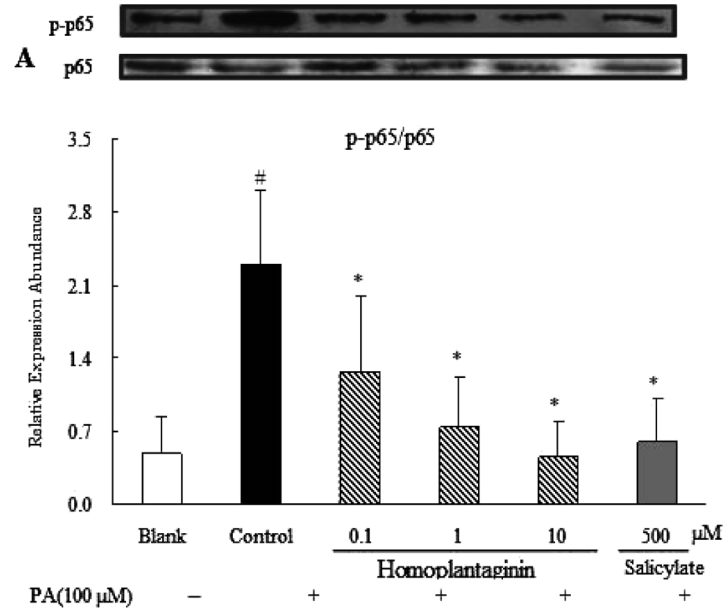

B
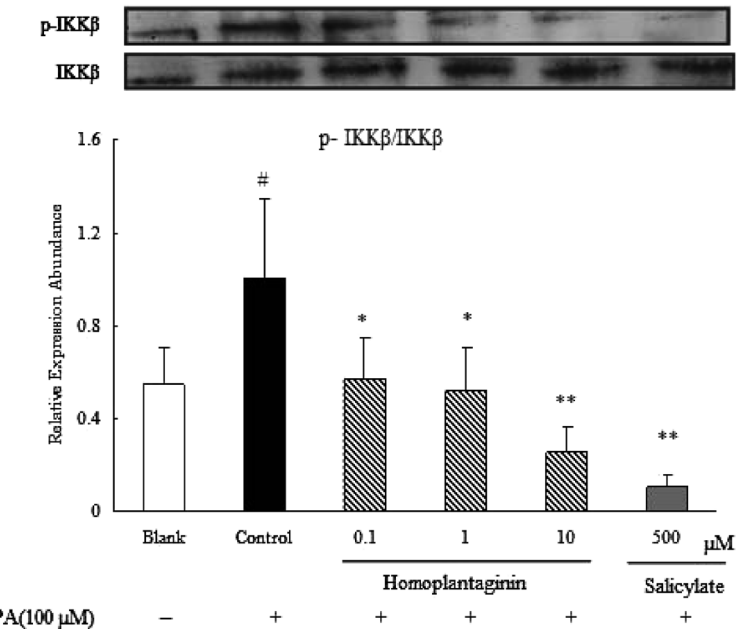

Fig. 3. Effect of Homoplantaginin on IKK $\beta / \mathrm{NF}-\kappa \mathrm{B}$ Activation in PATreated HUVECs

HUVECs were pretreated with homoplantaginin or salicylate before being stimulated with PA $(100 \mu \mathrm{M})$ for $3 \mathrm{~h}$. "Blank" and "control" indicate the absence or presence of PA, respectively. IKK $\beta$ and $\mathrm{p} 65$ protein phosphorylation was assessed using Western blot analysis. The data shown are expressed as the mean values \pm S.D. of four independent experiments. ${ }^{\#} p<0.05$ versus. blank; ${ }^{*} p<0.05$, $* * p<0.01$ versus control.

sodium salicylate significantly blocked PA-induced decreases in NO production (Fig. 6B). Compared to control, NO production was increased by up to $54 \%$ and $45 \%$ with $0.1,1 \mu \mathrm{M}$ homoplantaginin, respectively.

\section{DISCUSSION}

The insulin resistance syndrome refers to a constellation of findings, including glucose intolerance, obesity, dyslipidemia, and hypertension, that promote the development of type 2 diabetes, cardiovascular disease, cancer, and other disorders. ${ }^{15}$ ) Insulin resistance is a central component of metabolic syndrome and an important pathophysiological factor in the development of type 2 diabetes as well as cardiovascular diseases. ${ }^{16)}$ Endothelial dysfunction is commonly observed in association with type 2 diabetes and other situations characterised by insulin resistance. ${ }^{17-19)}$ Insulin resistance and endothelial dysfunction may co-exist, where chronic inflammation may be a crucial factor. The early onset of vascular inflammation was accompanied by biochemical evidence of both endothelial

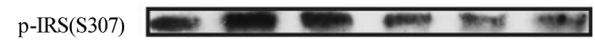

IRS
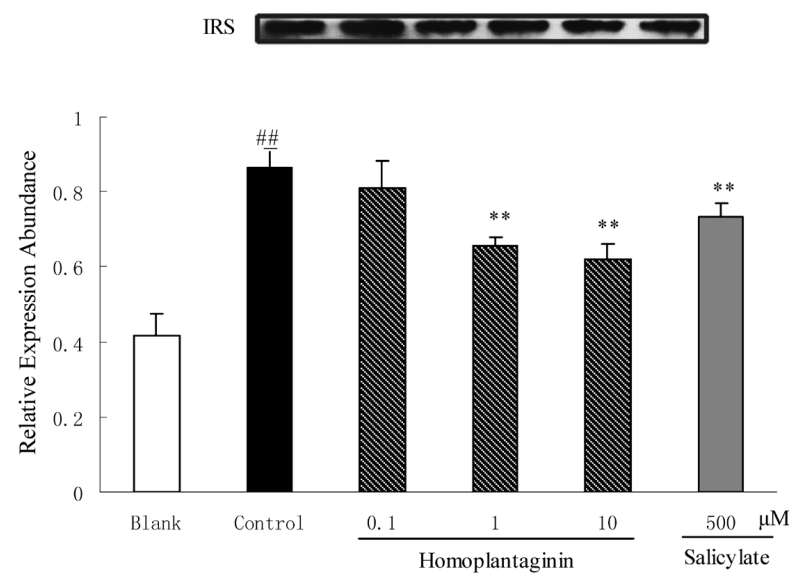

$\operatorname{PA}(100 \mu \mathrm{M})$

Fig. 4. Effect of Homoplantaginin on Serine Phosphorylation of IRS-1 in PA-Stimulated HUVECs

HUVECs were pretreated with homoplantaginin or salicylate for $30 \mathrm{~min}$ before being incubated with $100 \mu \mathrm{M}$ PA for $3 \mathrm{~h}$. "Blank" and "control" indicate the absence or presence of PA, respectively. Protein phosphorylation levels were determined using Western blot analysis. The bar graphs show p-IRS (S307) levels as a percentage of IRS expression. The data shown are expressed as the mean values \pm S.D. of three independent experiments. ${ }^{\# \#} p<0.01$ versus blank; $* * p<0.01$ versus control.

dysfunction (i.e. reduced nitric oxide production, induction of intracellular adhesion molecule-1 and vascular cell adhesion molecule-1) and insulin resistance (impaired insulin-induced phosphorylation of Akt and eNOS). ${ }^{20)}$

Previous study related to the interplay between obesity, inflammation and insulin resistance revealed that TNF expression was elevated in adipose tissues isolated from multiple experimental models of obesity. ${ }^{21,22)}$ Subsequently, similar correlations between TNF levels, obesity and insulin resistance in humans were suggested. ${ }^{23)} \mathrm{TNF}-\alpha$, as one of the proinflammatory cytokines, was shown to interrupt the early insulinstimulated tyrosine phosphorylation events, which is crucial to insulin transmembrane signaling. ${ }^{24)}$ Interleukin (IL)-6 is released in substantial amounts not only by monocytes and hepatic Kupffer cells, but also by endothelial cells, skeletal muscle cells, and adipocytes. ${ }^{25}$ ) In addition, IL-6 is another inflammatory cytokines known to be elevated in obesity and correlated with insulin resistance. ${ }^{26,27)}$ Therefore, TNF- $\alpha$ and IL-6 seems to be crucial player in the metabolic syndrome.

Obesity-linked insulin resistance is associated with chronic inflammation and cardiovascular complications. Free fatty acids (FFAs) are prominent candidates for the molecular link between these disorders. High levels of plasma FFAs impair endothelial function and are associated with a number of cardiovascular risk factors linked to insulin resistance, including hypertension, dyslipidemia, and abnormal fibrinolysis. ${ }^{7)}$ FFAs could induce inflammatory response and insulin resistance in macrophages, adipocytes and endothelial cells through the innate immune receptor Toll-like receptor-4 (TLR4). ${ }^{28,29)}$ In this context, PA, one of the richest FFAs in the plasma of obesity patients, was chosen as a pathogenic agent to induce inflammatory response and insulin resistance in cultured endothelial cells. Our results showed that, IL-6 and TNF- $\alpha$ mRNA levels significantly increased in HUVECs exposed to PA $(100 \mu \mathrm{M})$. Pretreatment of homoplantaginin concentration-dependently suppressed IL-6 and TNF- $\alpha$ mRNA expression. These results 
$\mathbf{A}$

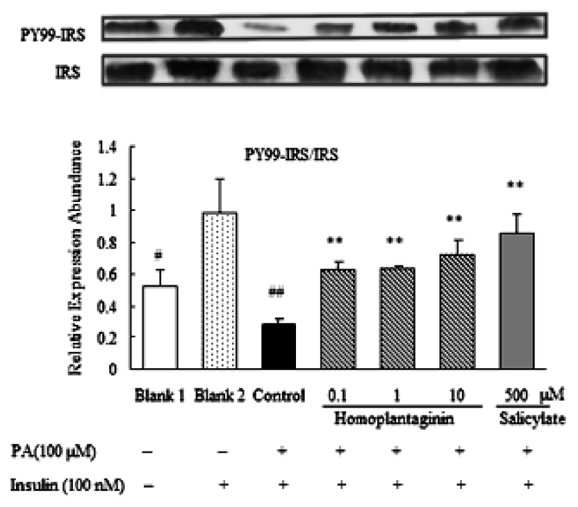

B
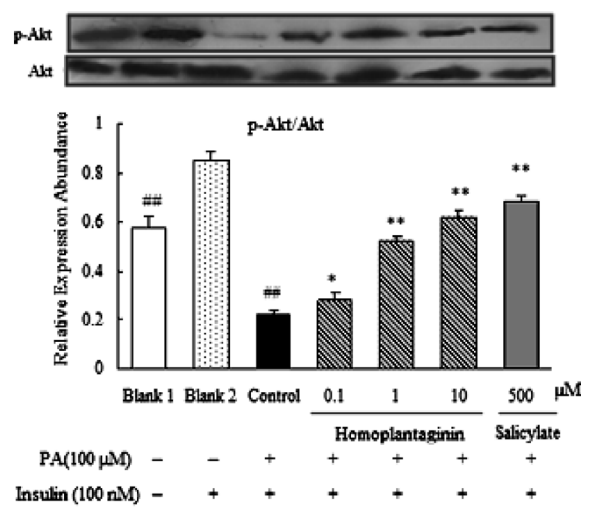

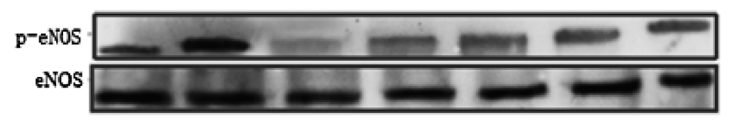

C

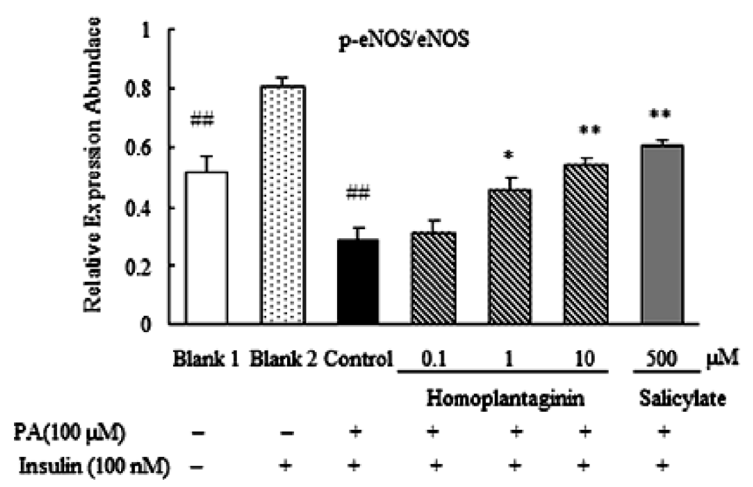

Fig. 5. Effects of Homoplantaginin on the Tyrosine Phosphorylation of IRS-1 and Phosphorylation of Akt, eNOS in HUVECs

HUVECs were incubated with PA $(100 \mu \mathrm{M})$ for $3 \mathrm{~h}$ before being treated with insulin $(100 \mathrm{~nm})$ for 15 min. Cells were pretreated with either homoplantaginin or salicylate for $30 \mathrm{~min}$ prior to treatment with PA. Protein phosphorylation levels were determined using western blot analysis. The bar graphs show PY99-IRS levels as a percentage of IRS expression. The bar graphs also show p-Akt levels as a percentage of Akt expression and p-eNOS levels as a percentage of eNOS expression. The data are expressed as the mean values \pm S.D. of four independent experiments. ${ }^{\#} p<0.05,{ }^{\#} p<0.01$ versus blank $2 ; *^{*} p<0.05, * * p<0.01$ versus control.

indicated that homoplantaginin inhibited vascular inflammation by down-regulation of TNF- $\alpha$ and IL- 6 gene expression (Fig. 2).

IKK is made up of two kinases, IKK $\alpha$ and $\operatorname{IKK} \beta$. IKK $\beta$ is the primary subunit of the IKK complex involved in mediating the proinflammatory signal-induced phosphorylation of NF- $\kappa \mathrm{B}$ inhibitory protein $(\mathrm{I} \kappa \mathrm{B} \alpha)$, which leads to the degradation of $\mathrm{I} \kappa \mathrm{B} \alpha$ and the consequent activation of $\mathrm{NF}-\kappa \mathrm{B} \cdot{ }^{30,31)} \mathrm{NF}-\kappa \mathrm{B}$ is a critical mediator of inflammation progress and regulates the expression of a wide range of inflammatory molecules such as inducible nitric oxide synthase, cyclooxygenase-2, IL-6 and TNF- $\alpha{ }^{32)}$ In the present study, PA induced IKK $\beta$ activation in endothelial cells, which subsequently promoted the activation of NF- $\kappa \mathrm{B}$, a transcription factor associated with inflammation. Moreover, endothelial cells treated with homoplantaginin, the phosphorylation of IKK $\beta$ was significantly reduced and the activation of NF- $\kappa \mathrm{B}$ was remarkbly inhibited (Fig. 3). These results suggested that homoplantaginin inhibited PA induced TNF- $\alpha$ and IL- 6 gene expression by an IKK $\beta / \mathrm{NF}-\kappa \mathrm{B}-$ dependent pathway in endothelial cells.

Many evidences have showed that activation or overexpression of IKK $\beta$ will attenuate the insulin signalling. Salicylate acting as inhibitors of IKK- $\beta$ and NF- $\kappa \mathrm{B}$, could be used to treat insulin resistance and type 2 diabetes. ${ }^{33)}$ At the molecular level, inhibition of IKK $\beta$ prevented the Ser/Thr phosphorylation of IRS-1, whereas it improved the insulinstimulated Tyr phosphorylation of IRS-1, thus implicating IKK $\beta$ as the IRS kinase. ${ }^{34)}$ Recent data suggest that IRS-1 may be directly phosphorylated by IKK $\beta$ at serine residues. ${ }^{7)}$ Phosphorylation of the serine residue of IRS-1 blocks the interaction between the tyrosine residue of IRS-1 and the insulin receptor. This subsequently affects the PI3K/Akt pathway, in turn reducing endothelial eNOS transcription and NO generation and ultimately resulting in insulin resistance. ${ }^{4,21)}$ These findings may represent a mechanism by which the inflammatory pathways contribute to impaired insulin signaling.

In the current study, we further investigated whether homoplantaginin could ameliorate insulin sensitivity via its inhibition of IRS-1 (Ser307) phosphorylation. Our results showed that pretreatment with homoplantaginin and sodium salicylate reduced the PA-induced phosphorylation of the IRS-1 serine residue (Ser307) (Fig. 4). The inhibition of homoplantaginin on NF- $\kappa$ B-dependent inflammation might be responsible for the PA induced down-regulation of IRS-1 serine phosphorylation.

Endothelial-derived NO plays a key role in maintaining normal endothelial function, which includes inhibition of thrombosis and vascular inflammation and maintaining blood pressure and vessel patency. NO also inhibits abnormal growth and inflammation, exerts antiaggregatory effects on 

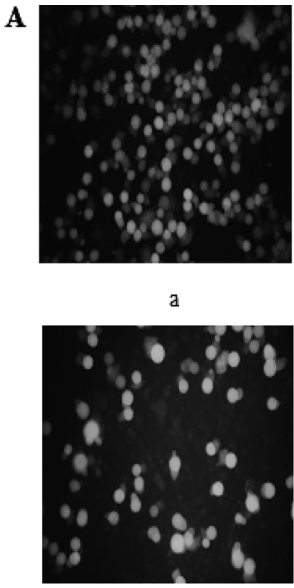

d

B

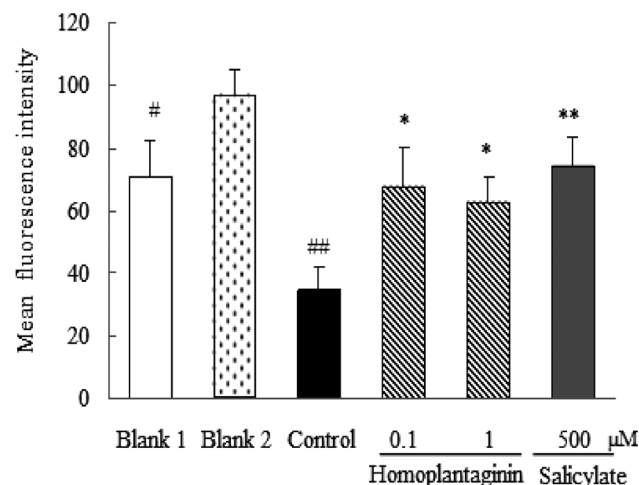

$\mathrm{PA}(100 \mu \mathrm{M})$ Insulin ( $100 \mathrm{nM})$

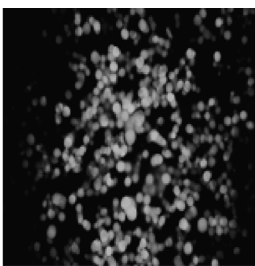

b

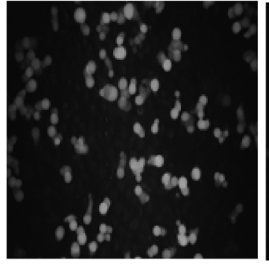

e

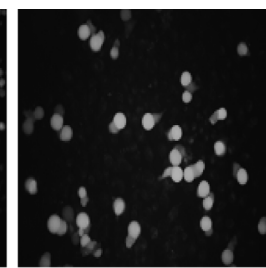

c

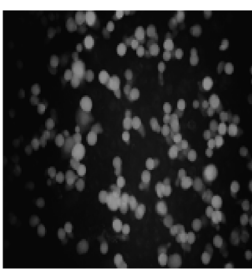

$\mathrm{f}$
Fig. 6. Effect of Homoplantaginin on NO Production in PA-Treated HUVECs

Photographs are representative fluorescent images of HUVECs treated with DAF-FM DA. The images shown were captured $5 \mathrm{~min}$ after the cells were stimulated with insulin. A: a, Blank 1, Image of cells with no drug treatment; b, Blank 2 , Image of cells with cultured with $100 \mathrm{~nm}$ insulin; c, control; d, $0.1 \mu \mathrm{M}$ homoplantaginin; e, $1 \mu \mathrm{M}$ homoplantaginin; f, $500 \mu \mathrm{m}$ Salicylate. Magnification: $\times 200$. B The bar graphs show fluorescence intensity represented NO production in endothelia cells. The data shown are expressed as the mean values \pm S.D. of three independent experiments. ${ }^{\#} p<0.05,{ }^{\#} p<0.01$ versus blank $2 ;{ }^{*} p<0.05,{ }^{*} * p<0.01$ versus control.

platelets, and promotes vasodilation. Previous work has demonstrated that the IRS-1/PI3-kinase/pAkt/peNOS pathway is important for endothelial NO production. Transfection with mutated IRS-1, inhibitory PI3-kinase mutants, or dominantnegative Akt abrogate insulin dependent NO production. ${ }^{7}$ Many of the metabolic abnormalities found in diabetes and obesity, which include elevation of TNF- $\alpha$ and metabolites such as FFAs, have been shown to have negative effects on the IRS-1/PI3-kinase signaling pathway in myocytes and hepatocytes. Our data indicated that PA impaired insulin-dependent NO production through downregulation of cell signaling via the IRS-1/pAkt/peNOS pathway. As expected, we found that homoplantaginin inhibited IRS-1 serine phosphorylation of (Ser307), subsequently enhancing IRS-1 Tyr phosphorylation (PY99) (Fig. 5A), PI3-kinase activation (T308) (Fig. 5B), eNOS phosphorylation (Fig. 5C), and, ultimately improved NO production (Fig. 6).

In summary, the present study demonstrates that homoplantaginin ameliorates endothelial insulin resistance by inhibiting inflammation and modulating cell signalling via the IKK $\beta$ /
IRS-1/pAkt/peNOS pathway. Previously, we have demonstrated that homoplantaginin could attenuate hyperlipidemia and hyperglycemia in diabetic mice. Thus, homoplantaginin may potentially be used for the prevention and treatment of cardiovascular disease associated with insulin resistance and diabetes.

Acknowledgements This work was supported by the Priority Academic Program Development of Jiangsu Higher Education Institutions. We are grateful to Prof. Liu Baolin for his assistance with subject recruitment and excellent technical assistance.

\section{REFERENCES}

1) Calles-Escandon J, Cipolla M. Diabetes and endothelial dysfunction: a clinical perspective. Endocr. Rev., 22, 36-52 (2001).

2) Kim F, Gallis B, Corson MA. TNF- $\alpha$ inhibits flow and insulin signaling leading to NO production in aortic endothelial cells. Am. J. Physiol. Cell Physiol., 280, C1057-C1065 (2001).

3) Kim ED, Bayaraa T, Shin EJ, Hyun CK. Fibroin-derived peptides stimulate glucose transport in normal and insulin-resistant 3T3-L1 adipocytes. Biol. Pharm. Bull., 32, 427-433 (2009).

4) Montagnani M, Ravichandran LV, Chen H, Esposito DL, Quon MJ. Insulin receptor substrate-1 and phosphoinositide-dependent kinase-1 are required for insulin-stimulated production of nitric oxide in endothelial cells. Mol. Endocrinol., 16, 1931-1942 (2002).

5) Young VM, Toborek M, Yang F, McClain CJ, Hennig B. Effect of linoleic acid on endothelial cell inflammatory mediators. Metabolism, 47, 566-572 (1998).

6) Jiao K, Liu HL, Chen JK, Tian DM, Hou JF, Kaye AD. Roles of plasma interleukin- 6 and tumor necrosis factor- $\alpha$ and FFA and TG in the development of insulin resistance induced by high-fat diet. Cytokine, 42, 161-169 (2008).

7) Kim F, Tysseling KA, Rice J, Pham M, Haji L, Gallis BM, Baas AS, Paramsothy P, Giachelli CM, Corson MA, Raines EW. Free fatty acid impairment of nitric oxide production in endothelial cells is mediated by IKK $\beta$. Arterioscler. Thromb. Vasc. Biol., 25, 989-994 (2005).

8) Ding P, Tian YQ. Study progress on the Chinese herb Salvia plebeia R. BR. Anhui Nongye Kexue, 36, 4133-4134 (2008).

9) Jin XF, Lu YH, Wei DZ, Wang ZT. Chemical fingerprint and quantitative analysis of Salvia plebeia R. BR. by high-performance liquid chromatography. J. Pharm. Biomed. Anal., 48, 100-104 (2008).

10) Weng XC, Wang W. Antioxidant activity of compounds isolated from Salvia plebeia. Food Chem., 71, 489-493 (2000).

11) Qu XJ, Xia X, Wang YS, Song MJ, Liu LL, Xie YY, Cheng YN, Liu XJ, Qiu LL, Xiang L, Gao JJ, Zhang XF, Cui SX. Protective effects of Salvia plebeia compound homoplantaginin on hepatocyte injury. Food Chem. Toxicol., 47, 1710-1715 (2009).

12) Wu FH, Liang JH, Wang H, Li WG. China Patent Application number 201110024707.2 (2011).

13) Wu FH, Liang JH, Chen R, Wang QZ, Li WG. Chemical constituents and hepatoprotective activity of plantago depressa var. montata kitag. Zhongguo Tianran Yaowu, 4, 435-439 (2006).

14) Liu HT, Li WM, Xu G, Li XY, Bai XF, Wei P, Yu C, Du YG. Chitosan oligosaccharides attenuate hydrogen peroxide-induced stress injury in human umbilical vein endothelial cells. Pharmacol. Res., 59, 167-175 (2009).

15) Saltiel AR, Kahn CR. Insulin signalling and the regulation of glucose and lipid metabolism. Nature, 414, 799-806 (2001).

16) Biddinger SB, Kahn CR. From mice to men: insights into the insulin resistance syndromes. Annu. Rev. Physiol., 68, 123-158 (2006).

17) Neunteufl T, Heher S, Katzenschlager R, Wölfl G, Kostner K, Maurer $\mathrm{G}$, Weidinger F. Late prognostic value of flow-mediated dilation 
in the brachial artery of patients with chest pain. Am. J. Cardiol., 86, 207-210 (2000).

18) Schächinger V, Britten MB, Zeiher AM. Prognostic impact of coronary vasodilator dysfunction on adverse long-term outcome of coronary heart disease. Circulation, 101, 1899-1906 (2000).

19) Suwaidi JA, Hamasaki S, Higano ST, Nishimura RA, Holmes DR Jr, Lerman A. Long-term follow-up of patients with mild coronary artery disease and endothelial dysfunction. Circulation, 101, 948954 (2000).

20) Kim F, Pham M, Maloney E, Rizzo NO, Morton GJ, Wisse BE, Kirk EA, Chait A, Schwartz MW. Vascular inflammation, insulin resistance, and reduced nitric oxide production precede the onset of peripheral insulin resistance. Arterioscler. Thromb. Vasc. Biol., 28, 1982-1988 (2008).

21) Hotamisligil GS, Shargill NS, Spiegelman BM. Adipose expression of tumor necrosis factor- $\alpha$ : direct role in obesity-linked insulin resistance. Science, 259, 87-91 (1993).

22) Hotamisligil GS, Spiegelman BM. Tumor necrosis factor alpha: a key component of the obesity-diabetes link. Diabetes, 43, 12711278 (1994).

23) Hotamisligil GS, Arner P, Caro JF, Atkinson RL, Spiegelman BM. Increased adipose tissue expression of tumor necrosis factor- $\alpha$ in human obesity and insulin resistance. J. Clin. Invest., 95, 24092415 (1995).

24) Feinstein R, Kanety H, Papa MZ, Lunenfeld B, Karasik A. Tumor necrosis factor- $\alpha$ suppresses insulin-induced tyrosine phosphorylation of insulin receptor and its substrates. J. Biol. Chem., 268, 26055-26058 (1993).

25) Staiger H, Staiger K, Stefan N, Wahl HG, Machicao F, Kellerer M, Häring HU. Palmitate-induced interleukin-6 expression in human coronary artery endothelial cells. Diabetes, 53, 3209-3216 (2004).
26) Kern PA, Ranganathan S, Li CL, Wood L, Ranganathan G. Adipose tissue tumor necrosis factor and interleukin-6 expression in human obesity and insulin resistance. Am. J. Physiol. Endocrinol. Metab., 280, E745-E751 (2001).

27) Pradhan AD, Manson JE, Rifai N, Buring JE, Ridker PM. C-reactive protein, interleukin 6 , and risk of developing type 2 diabetes mellitus. JAMA, 286, 327-334 (2001).

28) Shi H, Kokoeva MV, Inouye K, Tzameli I, Yin HL, Flier JS. TLR4 links innate immunity and fatty acid-induced insulin resistance. $J$. Clin. Invest., 116, 3015-3025 (2006).

29) Kim F, Pham M, Luttrell I, Bannerman DD, Tupper J, Thaler J, Hawn TR, Raines EW, Schwartz MW. Toll-like receptor-4 mediates vascular inflammation and insulin resistance in diet-induced obesity. Circ. Res., 100, 1589-1596 (2007).

30) Arkan MC, Hevener AL, Greten FR, Maeda S, Li ZW, Long JM, Wynshaw-Boris A, Poli G, Olefsky J, Karin M. IKK-beta links inflammation to obesity-induced insulin resistance. Nat. Med., 11, 191-198 (2005).

31) Yin MJ, Yamamoto Y, Gaynor RB. The anti-inflammatory agents aspirin and salicylate inhibit the activity of I(kappa)B kinase-beta. Nature, 396, 77-80 (1998).

32) Bonizzi G, Karin M. The two NF-kappaB activation pathways and their role in innate and adaptive immunity. Trends Immunol., 25, 280-288 (2004).

33) Cai DS, Yuan MS, Frantz DF, Melendez PA, Hansen L, Lee J, Shoelson SE. Local and systemic insulin resistance resulting from hepatic activation of IKK- $\beta$ and NF-kappaB. Nat. Med., 11, 183-190 (2005).

34) Zick Y. Insulin resistance: a phosphorylation-based uncoupling of insulin signaling. Trends Cell Biol., 11, 437-441 (2001). 